\section{Using Bacteria to Quantify Arsenic Contamination in Potable Water}

Jan Roelof van der Meer*a, Michael Berg ${ }^{b}$, and Pham Thi Kim Trang ${ }^{c}$

${ }^{*}$ Correspondence: Prof. Dr. J.R. van der Meera

aUniversity of Lausanne, Department of Fundamental Microbiology, Bâtiment de

Biologie, CH-1015 Lausanne, Tel. +41 2169256 30, Fax: +41 2169256 05, E-Mail: JanRoelof.VanDerMeer@unil.ch

bEawag, Swiss Federal Institute of Aquatic Science and Technology, $\mathrm{CH}-8600$ Dübendorf

${ }^{\mathrm{C}}$ Centre for Environmental Technology and Sustainable Development (CETASD), Hanoi University of Science, Vietnam

Keywords: Arsenic analysis · Arsenite · Biosensor · Drinking water

Everyday quality measurements of drinking water usually rely on advanced chemical methods. However, for arsenic, which contaminates potable water in millions of family-based groundwater wells in Asia, this is no trivial business. To measure arsenic accurately, expensive machines such as AAS or ICP-MS are necessary. Such equipment is mostly absent in developing countries. Field test kits can be used as alternatives, but they are often unreliable at low arsenic concentrations. Accurate quantification of arsenic even at low concentrations is important to avoid chronic and toxic exposure, and the current WHO guideline for arsenic in drinking water is $10 \mu \mathrm{g} / \mathrm{l}$. Trang et al. recently reported the successful validation of a completely different analytical method that is based on light emission from engineered bacterial cells.

\section{From the laboratory ...}

How can bacterial cells detect arsenic and emit light? In order to do so, Stocker et al. equipped Escherichia coli bacteria with the ArsR protein, which is a naturally occurring arsenite-sensing protein in the bacterial arsenic-detoxification system. By genetic engineering techniques they then created a circuit in which ArsR controls the expression of a reporter protein, such as the enzyme luciferase. When the cells encounter arsenite, luciferase is synthesized and the cells start to emit light, which can be easily measured. Within a certain range the light emission is proportional to the arsenite exposure.

\section{... to the field}

A set of simple bioassays was designed on this principle enabling the accurate detection of arsenic in aqueous samples with widely different chemical composition and within 30 min to $2 \mathrm{~h}$. To validate the bioassay performance in analyzing arsenic in real groundwaters, we recently used the light-emitting biosensors in a region in Vietnam where Berg et al. had reported serious arsenic contamination. A total of 194 groundwater samples were collected in the Red River and Mekong River Delta and analyzed both by AAS and by the arsenic bioassay. Compared to AAS the bacterial assay falsely predicted samples to have less than $10 \mu \mathrm{g}$ arsenic per liter in $8 \%$ and more in $2.4 \%$ of all cases, which is far better than the performance of chemical field test kits and thus holds great promise for their use in drinking water analysis in developing countries.

Received: July 11, 2006

\section{References}

P.T.K. Trang, M. Berg, P.H. Viet, N.V. Mui, J.R. van der Meer, Environ. Sci. Technol. 2005, 39, 7625.

J. Stocker, D. Balluch, M. Gsell, H. Harms, J.S. Feliciano, S. Daunert, K.A. Malik, J.R. van der Meer, Environ. Sci. Technol. 2003, 37, 4743.

M. Berg, H.C. Tran, T.C. Nguyen, H.V. Pham, R. Schertenleib, W. Giger, Environ. Sci. Technol. 2001, 35, 2621. light emission (rel. units)

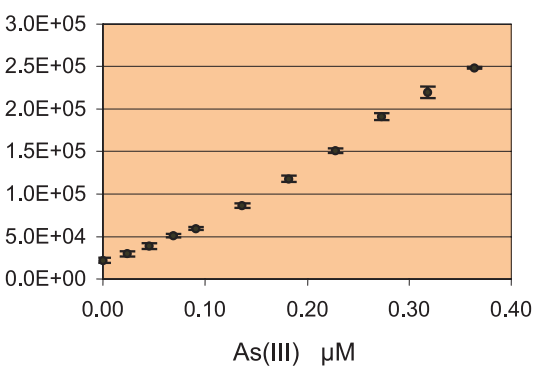

Calibration curve with the bioluminescent arsenic biosensor. Incubation time: $1.5 \mathrm{~h}$ at $30^{\circ} \mathrm{C}$. Measurement: Luminometer plate reader.

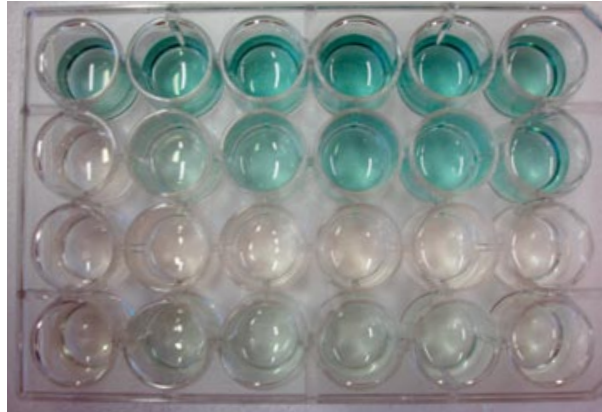

Colorimetric arsenic bioassay. Cells produce beta-galactosidase in response to the presence of arsenite in the medium. Image shows different cell lines (in rows) with varying response kinetics. Arsenite concentrations (left to right): $0,0.1,0.2$, $0.5,1.0$ and $2.0 \mu \mathrm{M}$. Incubation time $3 \mathrm{~h}$ at $35^{\circ} \mathrm{C}$ Image courtesy: Jan R. van der Meer.

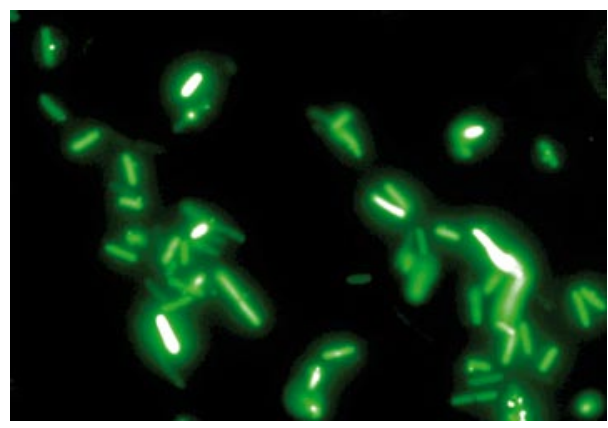

Escherichia coli bacteria producing Green Fluorescent Protein in response to the presence of arsenite in the medium. The GFP signal can be quantified by epifluorescence microscopy, but more easily in steady state fluorimetry. Incubation time: $2.5 \mathrm{~h}$ at $30^{\circ} \mathrm{C}$ with $0.5 \mu \mathrm{M}$ As(III). Image courtesy: Jan R. van der Meer. 